\title{
Pembaharuan Hukum Kontrak sebagai Antisipasi Transaksi Electronic Commerce
}

\author{
Ridwan Khairandy
}

\begin{abstract}
The following article examines the possible reformation of the contract law in relation to the rising use of online contract in commercial business activities. It's generally recognized that the conventional contract law has been unable to overcome various legal problems stemming from online contract. There are three ways to reform such a contract law, namely: (1) through legislation by adopting some existing models of law; (2) through the establishment of customary law like lex mercatoria; (3) through cases law. Though the arrangement through legislation is done partially, but the substance must be integrative so that it can run toward a cyberspace.
\end{abstract}

\section{Pendahuluan}

Revolusi yang dibawa teknologi informasi (termasuk :konvergensi antara teknologi komputer dan teknologi komunikasi) menjadikan dunia sebagai sebuah global village dengan ekonomi globalnya. Perkembangan teknologi informasi terakhir, khususnya ledakan informasi di dalam dunia maya (cyberspace) ${ }^{1}$ dan Internet membawa perubahan ke segala aspek kehidupan manusia, pendidikan, perdagangan, hiburan, pemerintahan, dan komukasi. $^{3}$
Sistem transaksi perdagangan yang semula berbasis kertas bergeser ke sistem transaksi yang berbasis pada non kertas (digital). Kehadiran teknologi informasi sekarang ini sedikitnya membawa dua implikasi. Implikasi itu berdampak di sektor ekonomi dan sektor hukum. Di sektor ekonomi kehadiran internet cenderung membawa iklim yang makin transparan, efektif, dan efisien. Di lain pihak kehadiran internet pada sektor hukum memunculkan berbagai persoalan

'Seiring dengan meluasnya penggunaan komputer istilah cyberspace menunjuk kepada sebuah ruang elektronik (electronic space), yakni sebuah masyarakat virtual yang terbentuk melalui komunikasi yang terjalin dalam sebuah jaringan komputer (interconnected computernetworks).

${ }^{2}$ Sejumlah permasalahan yang timbul dengan adanya teknologi akan terus berkembang seiring dengan perkembangan teknologi itu sendiri. Secara historis, lahirnya berbagai penemuan-penemuan baru di bidang teknologi pada abad delapan belas yang kemudian diringi dengan revolusi industri menimbulkan sejumlah masalah hukum yang perlu pemecahannya sesuai dengan zamannya. Perkembangan informasi teknologi yang 
hukum yang mendasar. ${ }^{2}$ Problem utama yang berkaitan dengan transaksi.e-commerce ini di Indonesia bukan di aspek teknologinya, tetapi justeru di aspek regulasinya. ${ }^{3}$

Salah satu permasalahan hukum itu adalah berkaitan dengan hukum kontrak. Sampai saat ini diakui bahwa aturan hukum kontrak konvensional belum mampu menjangkau sepenuhnya terhadap model kontrak yang dilakukan secara elektronik (electronic contract).

Keadaan di atas menunjukkan adanya anggapan yang menyatakan hukum selalu ketinggalan dengan perkembangan kegiatan masyarakat (het rechts achter feiten aan) makin sulit dibantah. Keadaan ini semestinya mendorong akan perlunya suatu pemikiran pembaharuan hukum kontrak konvensional untuk kontrak yang dilakukan dengan menggunakan media elektronik.

\section{E-Commerce dan E-Business}

E-commerce diaplikasikan pada awal 1970-an dengan beberapa inovasi dari Electronic Fund Transfer (EFT). Bagaimana pun aplikasi yang ada dibatasi oleh luasnya perusahaan, institusi keuangan, dan sedikit keberanian dari industri kecil. Kemudian menghadirkan Electronic Data Interchange (EDI) yang diperluas dari transaksi keuangan ke proses transaksi lainnya, dan memperluas partisipasi perusahaan dari institusi keuangan ke manufaktur, retail, jasa, dan sebagainya. Banyak aplikasi lain mengikutinya, yakni dari perdagangan stok ke sistem reservasi travel, seperti sistem-sistem yang menjelaskan aplikasi telekomunikasi dan strategi nilai mereka diakui secara luas. ${ }^{4}$

Dengan komersialisasi internet pada awal 1990-an telah meningkatkan costumer potensial sebanyak satu juta. Selanjutnya ecommerce diperluas dengan membangun teknologi melalui jaringan, protokol, bersifat lunak (software) dan spesifikasinya. Alasan lainnya adalah meningkatkan kompetisi dan tekanan bisnis lain. Dari 1995 sampai 1999 dapat dilihat banyaknya inovasi aplikasi pengiklanan (advertisement) ke pelelangan (auction) dan pengalaman virtual. Di Amerika serikat hampir setiap organisasi menengah ke atas mempunyai website. Sebagai contoh pada tahun 1998 General Motors Corporations menawarkan 18.000 halaman informasi yang mencakup 98.000 jaringan ke produk, jasa, dan dealer $\mathrm{GM}^{5}$

Sampai sekarang belum didapat satu pengertian atau definisi e-commerce yang seragam. Hal ini disebabkan karena perkembangan e-commerce yang sangat pesat, sehingga hampir setiap saat e-commerce ini mengalami perubahan dan melahirkan bentuk baru. Tidak berarti dengan tidak ada pengertian yang seragam itu

terjadi sekarang menimbulkan permasalahan hukum yang lebih komplek lagi. Perhatikan Assafa Endeshaw. 2001. Internet and E-Commerce Law with Focus on Asia Pacific. Prentice Hall. Singapore. HIm 3-4.

${ }^{3}$ Warta Ekonomi. 8 Januari 2001.

${ }^{4 E f r a i m ~ T u r b a n, ~ e t, a l . ~ 1999 . ~ E l e c t r o n i c ~ C o m m e r c e ~ P e r s p e c t i v e ~ M a n a g e r i a l . ~ P r e n t i c e-H a l l, ~ I n c ~ N e w ~}$ Jersey. HIm.13.

${ }^{5}$ lbid. 
mengakibatkan tidak ada sama sekali pengertian e-commerce.

Electronic commerce adalah konsep yang menjelaskan proses pembelian dan penjualan dari suatu produk barang, jasa, dan informasi melalui jaringan komputer yang 'melingkupi internet. Black's Law Dictionary, mendefinisikan e-commerce sebagai berikut: 6

"The practice of buying and selling good's and services through online consumer services on the internet. The $e, a$ shortened form of electronic, has become a popular prefix for other terms associated with electronic transaction".

Dengan demikian, dapat dikatakan bahwa pengertian e-commerce adalah pembelian dan penjualan barang dan jasa dengan menggunakan jasa konsumen online di internet. Model transaksi seperti ini dikenal dengan istilah electronic transaction. Dalam kamus yang sama electronic transaction dijelaskan a transaction formed by electronic messages in which the massages of one or both parties will not be reviewed by an individual as an expected step in forming a contract. ${ }^{7}$ Menurut ECEG-Australia (Electronic Commerce Expert Group), e-commerce adalah:

"is a broad concept that covers any commercial transaction that is effected via electronic means and would include such means as facsimile, telex, EDI, intemet and the telephone". ${ }^{8}$
Berdasarkan pengertian yang diberikan ECEG - Australia di atas, maka e-commerce meliputi transaksi perdagangan melalui media elektronik. Dalam pengertian tidak hanya media internet yang dimaksudkan, tetapi juga meliputi semua transaksi perdagangan melalui media elektronik lain, seperti; faksimili, telex, EDI, dan telepon. Julian Ding merumuskan definisi e-commerce yang lain, yakni:

"Electronic commerce ore-commerce as it is also know, is a commercial transaction between a vendor and purchaser or parties in similar contractual relationships for the supplay of goods, services or the acquisition of "rights". This commercial transaction is executed or entered into in an electronic medium (or digital medium) where the physical presences of the parties is not required and the medium exist in a public network or system as opposed to a private network (closed system). The public network or system must be considered an open system (e.g. the internet or the world wide web). Two transaction are concluded regardless of national boundaries or local requirements". 9

Dalam mendefinisikan e-commerce, Kalakota dan Whinston melihat e-commerce dari berbagai macam perspektif, di antaranya: ${ }^{10}$

${ }^{6}$ Bryan A Garner et.al (eds). 1999. Black's Law Dictionary.Seventh Edition, West Group St. Paul Minn, HIm. 530.

7 Ibid.

${ }^{8} \mathrm{http} / /$ www.law.gov.au/aghome/advisory/eceg/single.htm

9 Julian Ding. 1999. E-Commerce: Law and Practice. Sweet \& Maxwell, Kuala Lumpur. HIm. 25.

${ }^{10}$ Efraim Turban, et,al, Op.Cit, HIm 4. 
Dari perspektif komunikasi, e-commerce adalah penyerahan informasi, produk barang atau jasa, atau pembayaran melalui jaringan telepon, jaringan komputer, atau dengan maksud elektronik lainnya.

Dari perspektif proses bisnis, e-commerce adalah aplikasi dari teknologi melalui transaksi bisnis otomatis dan aliran kerja.

Dari perspektif pelayanan, e-commerce adalah alat (a tool) yang mengalamatkan hasrat dari perusahaan, konsumen, dan menajemen untuk memotong biaya pelayanan, dan dapat memperbaiki kualitas barang dan mempercepat pelayanan.

Dari perspektif online, e-commerce menyediakan kemampuan pembelian dan penjualan produk dan informasi di internet dan jasa online lainnya.

Istilah commerce ditinjau dari beberapa perilaku transaksi antar mitra bisnis. Oleh karena itu, istilah e-commerce tampaknya menjadi terbatas untuk beberapa orang tertentu saja. Kemudian dipergunakanlah istilah lain, yakni e-bussiness. Hal ini merujuk kepada definisi e-commerce yang tidak hanya melakukan pembelian dan penjualan, tetapi juga pelayanan nasabah dan mengkolaborasi mitra bisnis, dan melakukan transaksi elektronik ke dalam suatu organisasi. Hubungan antara e-commerce dan e-bisiness ini ditegaskan lagi oleh Lou Garstner IBM's CEO yang menyatakan: " $E$-business is all about time cycle, speed globalization, enhanced productivity, reaching new customer and sharing knowledge across institutions for competitive advantage". ${ }^{11}$
Berdasarkan uraian di atas, dapat disimpulkan bahwa pengertian e-commerce tidak lagi sempit. Kegiatan e-commerce merupakan bagian dari e-business. Secara singkat dapat dikatakan e-commerce is a part of e-business.

Banyak orang mengira bahwa e-commerce hanya berkaitan dengan website, padahal ecommerce dapat dilihat lebih dari itu. Banyak aplikasi e-commerce untuk kepentingan lain seperti home banking, belanja di toko dan mall, online stok pembelian, mencari pekerjaan, melakukan pelelangan (auction) dan mengkolaborasikan elektronik dengan proyek pembangunan dan penelitian. Untuk melakukan hal ini dibutuhkan dukungan informasi dan sistem serta infrastruktur organisasi.

Inovasi dalam sejarah manusia telah memberi keuntungan potensial, seperti; ecommerce. Sifat global teknologi adalah biaya murah (low cost), kesempatan untuk memperkaya ratusan juta orang, dan sifat interaktif. Keuntungan ini tidak hanya memulai materialisasi, tetapi mereka akan meningkatkan secara signifikan dengan ekspansi e-commerce.

Berdasarkan realitas tersebut di atas, dapat dikemukakan beberapa keuntungan ecommerce bagi kepentingan organisasi, individu, dan masyarakat.

Keuntungan untuk organisasi di antaranya: Pertama, e-commerce memperluas tempat pemasaran untuk pasar nasional dan intemasional. Dengan minimnya modal sebuah perusahaan dapat dengan mudah dan cepat menemukan lebih banyak costumer, pemasok terbaik, dan mitra bisnis.yang pantas (suitable)

11 bid. 
di world wide. Kedua, e-commerce menurunkan biaya pembuatan, pemrosesan, pendistribusian, penyimpanan, dan pengembalian informasi melalui kertas.

Keuntungàn bagi konsumen dengan adanya e-commerce adalah: Pertama, melalui e-commerce konsumen dapat bertransaksi selama 24 jam dan dapat dilakukan di mana pun juga; Kedua, e-commerce menyediakan banyak pilihan bagi konsumen. Mereka dapat memiliki banyak vendor dari produk lainnya. Keuntungan bagi masyarakat, e-commerce dapat memfasilitasi kepentingan-kepentingan publik.

Di dalam tulisan ini yang dimaksud dengan kegiatan bisnis melalui media elektronik difokuskan pada proses transaksi melalui intemet. Penggunaan internet dipilih oleh kebanyakan orang sekarang ini karena kemudahan-kemudahan yang dimiliki jaringan internet: ${ }^{12}$

1. Internet sebagai jaringan publik yang sangat besar (huge/widespread network), layaknya yang dimiliki suatu jaringan publik elektronik, yaitu murah, cepat, dan kemudahan akses.

2. Menggunakan data elektronik sebagai media penyimpan pesan atau data sehingga dapat dilakukan pengiriman dan penerimaan informasi secara mudah dan singkat, baik dalam bentuk data elektronik analog maupun digital.
Di sisi lain pengguna media internet ini juga mempunyai kelemahan. Kelemahan ini muncul karena koneksi ke dalam jaringan internet sebagai jaringan publik merupakan koneksi yang tidak aman. Konsekuensinya $e$ commerce yang dilakukan dengan koneksi ke internet merupakan bentuk transaksi berisiko tinggi yang dilakukan di media yang tidak aman.

\section{Transaksi Electronic Commerce}

E-commerce telah melahirkan revolusi lain, di mana terjadi perubahan cara bisnis dalam penjualan dan pembelian produk dan pelayanan. $\mathrm{Hal}$ ini juga berkenaan dengan pembelian dan penjualan informasi, produk dan pelayanan melalui jaringan komunikasi komputer. E-commerce membantu pelaksanaan perdagangan tradisional melalui cara baru dalam mentransfer dan memproses informasi, karena informasi menjadi jantung dari aktivitas perdagangan apapun. Informasi secara elektronik ditransfer dari komputer ke komputer, secara otomatis. Kenyataannya hal ini telah mentransformasikan cara organisasi beroperasi. $^{13}$

Dalam dataran praktis e-commerce hanya dikenal dua macam, yaitu; Pertama, business to business e-commerce (B2B e-commerce), bentuk transaksi perdagangan ini melalui internet, yang dilakukan oleh dua perusahaan atau lebih perusahaan. Kedua, business to consumer ( $\mathrm{B2} \mathrm{C}$ e-commerce) yang merupakan

${ }^{12}$ Arrianto Mukti Wibowo, et,el. "Kerangka Hukum Digital Signature Dalam Electronic Commerce." Makalah disampaikan pada Masyarakat Telekomunikasi Indonesia. Diselenggarakan oleh UI. Depok Jawa Barat. Juni 1999. Hilm. 4.

${ }^{13}$ Kamlesh K Bajaj \& Debjani Bag. 2000. E-Commerce The Cutting Edge of Business. Diterjemahkan oleh Imam Mawardi. PT Akana Press Offset. Surabaya. HIm. 13. 
transaksi jual beli melalui internet antara penjual barang konsumsi dengan konsumen terakhir. ${ }^{14}$

Secara faktual, model transaksi di e-commerce mempunyai banyak ragam. Dari segi sifatnya transaksi di e-commerce dapat diklasifikasikan sebagai berikut: ${ }^{15}$

1. Business to business (B2B), model transaksi e-commerce ini banyak digunakan sekarang. Hal ini meliputi Interorganizational System (IOS) transaksi dengan segera dari transaksi pasar elektronik antar organisasi.

2. Business to consumer (B2C), transaksi retail dengan pembelanjaan (shopper) individu. Bentuk pembelanjaan seperti di Amazon.com adalah konsumen atau costumer.

3. Consumer to consumer $(\mathrm{C} 2 \mathrm{C})$, dalam katagori ini konsumen menjual dengan langsung untuk konsumen. Contohnya adalah individu menjual sesuatu yang diklasifikasikan ads (e.q. www.clasified2000.com) pemilikan kediaman (residential property), mobil, dan lain-lain. Pengiklanan jasa personal. di internet dan menjual ilmu pengetahuan dan keahlian contoh lain dari $\mathrm{C} 2 \mathrm{C}$. Beberapa situs pelelangan (auction) membolehkan individu untuk meletakkan barang. Pada akhirnya banyak individu menggunakan internet dan jaringan organisasi internal lainnya ke pelelangan barang untuk penjualan atau pelayanan.
4. Consumer to business (C2B); katagori ini meliputi individu yang menjual produk atau jasa untuk organisasi.

5. Nonbusiness e-commerce, meningkatkan sejumlah lembaga non-bisnis seperti; lembaga akademi, organisasi non profit, organisasi keagamaan, organisasi sosial, dan lembaga pemerintahan menggunakan bentuk e-commerce akan mengurangi pembiayaan mereka atau memperbaiki operasional mereka dan pelayanannya.

6. Intrabusiness organizational e-commerce, dalam katagori ini meliputi semua kegiatan organisasi internal, biasanya berupa internet.

Di dalam praktiknya model transaksi yang banyak dipakai oleh user/konsumen sampai saat ini adalah model Business to Business (B2B) dan Business to Consumer (B2C).

\section{Syarat-syarat Sahnya Kontrak}

Pasal 1320 KUHPerdata mensyaratkan bahwa untuk sahnya suatu perjanjian atau kontrak harus memenuhi empat syarat:

Pertama, sepakat bagi mereka yang mengikatkan dirinya. Kata sepakat di dalam perjanjian pada dasarnya adalah pertemuan atau persesuaian kehendak antara para pihak di dalam perjanjian. Seseorang dikatakan memberikan persetujuannya dan kesepakatannya jika ia memang menghendaki apa yang disepakati. ${ }^{16}$ Mariam Darus Badrulzaman melukiskan pengertian

${ }^{14}$ Muhammad Aulia Adnan. 2001. "Aspek Hukum Protokol Pembayaran Visa/Mastercard Secure Electronic Transaction (SET)." Skripsi, Fakultas Hukum Universitas Indonesia. Depok Jawa Barat. HIm.6.

${ }^{15}$ Efraim Turban, et, al, Op.Cit., HIm.10-11.

${ }^{16} \mathrm{~J}$. Satrio. Hukum Perikatan, Perikatan yang Lahir dari Perjanjian Buku I. Citra Aditya Bakti Bandung. 1995. HIm. 164. 
sepakat sebagai persyaratan kehendak yang disetujui (overeenstemende wilsverklaring) antar pihak-pihak. Pernyataan pihak yang menawarkan dinamakan (offerte). Pernyataan pihak yang menerima penawaran dinamakan akseptasi (acceptatie). ${ }^{7}$

Dengan demikian, penawaran dan akseptasi merupakan unsur yang sangat penting dalam menentukan lahirnya perjanjian. KUHPerdata Indonesia dan bahkan KUHPerdata Negara Belanda (Baru) sendiri tidak menjelaskan atau tidak memberikan patokan sejauhmana suatu penawaran dan/atau akseptasi itu mengikat. Artikel 6: 217 ayat (2) BW Baru Belanda hanya menyebutkan: "een overeenkomst komt tot stand door een aanbood en de aanvaarding daarvan." ${ }^{18}$

Mengingat tidak adanya definisi penawaran tersebut,. Rutten mendefiniskan penawaran sebagai suatu usul untuk menutup perjanjian yang ditujukan kepada pihak lawan janjinya, usul mana telah dirumuskan sedemikian rupa, sehingga penerimaan usul itu langsung menimbulkan perjanjian. ${ }^{19}$ Pemyataan kehendak tersebut harus merupakan pernyataan bahwa ia menghendaki timbulnya hubungan hukum.
Kesesuaian kehendak antara dua saja belum melahirkan perjanjian, karena kehendak itu harus dinyatakan, harus nyata bagi pihak yang lain. Apabila pihak yang lain tersebut telah menyatakan menerima atau menyetujuinya, maka timbullah kata sepakat.

Kedua, cakap untuk membuat suatu perikatan. Pasal 1329 KUHPerdata menyatakan bahwa setiap orang cakap untuk membuat perjanjian, kecuali apabila menurut undangundang dinyatakan tidak cakap. ${ }^{20}$ Dalam perkembangannya Mahkamah Agung melalui Putusan No. 447/Sip/1976 tanggal 13 Oktober 1976 menyatakan bahwa dengan berlakunya UU No. 1 Tahun 1974, maka batas seseorang berada di bawah kekuasaan perwalian adalah 18 tahun, bukan 21 tahun. Artikel 1: 233 KUHPerdata Belanda menentukan kedewasaan seseorang sekarang ini adalah jika telah berumur 18 tahun atau telah menikah. Di dalam sistem common law, seseorang dikatakan belum dewasa jika belum berumur 18 tahun (bagi wanita) dan 21 tahun (bagi pria). Dalam perkembangannya, umumnya negaranegara bagian di Amerika Serikat telah mensepakati bahwa kedewasaan tersebut

${ }^{17}$ Mariam Darus Badrulzaman. 1994. Aneka Hukum Bisnis, Alumni Bandung. Hlm. 24.

${ }^{18}$ R.J.Q Klomp (redakasi), Burgerlijk Wetboek 1997/1998 Boeken 1 t/m 8, Ars Aqequi Libr, Nijmegen, 1997. Terjemahan bahasa Inggrisnya adalah: A contact is formed by an offer and its acceptence. Lihat terjemahan BW Baru dalam Bahasa Inggris dan Perancis. P.P.C. Haanappel dan Ejan Mackaay, Nieuw Nederlands Burgerlijk Wetboek: Het Vermogenrechts. Kluwer Deventer. 1990.

18 J. Satrio. Op. Cit. HIm. 166.

${ }^{20}$ Dalam Pasal 1330 KUHPerdata dinyatakan bahwa ada beberapa orang tidak cakap untuk membuat perjanjian, yakni: (1) Orang yang belum dewasa; (2) Mereka yang ditaruh di bawah pengampuan; dan (3)Orang-orang perempuan.

Berkaitan dengan perempuan melalui Surat Edarannya (SEMA) Nomor 3 Tahun 1963 menetapkan bahwa perempuan demikian itu tetap cakap melakukan perjanjian. Pasal 31 ayat(2) UU No. 1 Tahun 1974 menentukan hal yang sama. Pasal 31 sub 2 UU No. 1 Tahun 1974 menentukan bahwa baik suami maupun istri berhak melakukan perbuatan hukum. 
ditentukan jika seseorang telah berumur 18 tahun yang berlaku baik bagi wanita maupun pria. ${ }^{21}$

Ketiga, suatu hal tertentu. Pasal $1333 \mathrm{KUH}-$ Perdata menentukan bahwa suatu perjanjian harus mempunyai pokok suatu benda yang paling sedikit dapat ditentukan jenisnya. J. Satrio menyimpulkan bahwa yang dimaksud dengan suatu hal tertentu dalam perjanjian adalah objek prestasi perjanjian. Isi prestasi tersebut harus tertentu atau paling sedikit dapat ditentukan jenisnya. ${ }^{22}$

Keempat, suatu sebab (causa) yang halal. Menurut Pasal 1335 jo 1337 KUHPerdata bahwa suatu kausa dinyatakan terlarang jika bertentangan dengan undang-undang, kesusilaan, dan ketertiban umum. Kausa hukum yang halal ini di dalam sistem common law disebut legality yang dikaitkan dengan public policy. Suatu kontrak dapat menjadi tidak sah (illegal) jika bertentangan dengan public policy. Walaupun sampai sekarang belum ada definisi public policy yang diterima secara luas, pengadilan memutuskan bahwa suatu kontrak bertentangan dengan public policy jika berdampak negatif pada masyarakat atau mengganggu keamanan dan kesejahteraan masyarakat (public's safety welfare). ${ }^{23}$

Hukum kontrak menganut beberapa prinsip; Pertama, prinsip konsensualisme, bahwa kontrak dinyatakan telah lahir "apabila telah ada kesepakatan di antara para pihak. ${ }^{24}$ Kedua, kebebasan berkontrak, artinya para pihak diberi kebebasan untuk bentuk dan isi suatu kontrak itu. Ketiga, Asas kekuatan mengikatnya kontrak. Dengan adanya kata sepakat tersebut menimbulkan kekuatan mengikatnya kontrak (pacta sunt servanda). ${ }^{25}$ Dalam prinsip ini terkandung bahwa kontrak yang dibuat oleh para pihak secara sah mengikat kedua belah pihak layaknya undangundang. Dengan perkataan lain apa yang disepakati keduabelah pihak menjadi undangundang bagi para pihak. Kebebasan berkontrak dan kekuatan mengikatnya kontrak antara lain dibatasi oleh iktikad baik. ${ }^{26}$

\section{Tipe-Tipe Kontrak Internet}

Santiago Cavanilas dan A, Martines Nadal menyatakan bahwa kontrak online dalam $e$ commerce memiliki banyak variasi, yakni: ${ }^{27}$

1. Kontrak melalui chatting dan video conference;

\footnotetext{
${ }^{21}$ Henry R. Cheseeman. 1995. Business Law: The Legal, Ethical and International Environment. Prentice Hall. New Jersey. HIm 197.

22J. Satrio. 1995. Hukum Perikatan, Perikatan yang Lahir dari Perjanjian Buku II. Citra Aditya Bakti. Bandung. Him. 41.

${ }^{23}$ Henry R. Cheseeman, Op. Cit ,Hlm 205.

${ }^{24}$ Lebih lanjut lihat Ridwan Khairandy, "Kewenangan Hakum untuk Melakukan Intervensi terhadap Kewajiban Kontraktual Berdasarkan Asas Iktikad Baik". Jurnal Hukum, No. 15 Vol 7 - 2000, Hilm 94.

${ }^{25} \mathrm{lbid}$. HIm 96.

${ }^{26} \mathrm{lbid}$. HIm 98.

${ }^{27}$ Santiago Cavanilas dan A. Martines Nadal, "Research Paper on Contract Law", ECLIP on Line, HIm 1: 3. Bandingkan dengan Elizabeth S. Perdue, "creating Contract Online", Thomas J. Smedinghoff (ed). 1996. Online Law The SPA's Legal Guide to Doing Business on the Internet. Addison-Wesley Developers Press, Reading. Hlm 85-86.
} 
2. Kontrak melalui e-mail; dan

3. Kontrak melalui Web (situs)

Chatting dan video conference merupakan alat komunikasi yang disediakan internet yang biasa digunakan untuk dialog interaktif secara langsung. Dengan chatting, seseorang dapat berkomunikasi secara langsung dengan orang lain sama dengan komunikasi melalui telepon, hanya saja komunikasi ini adalah pernyataan-pernyataan yang terbaca di masing-masing personal computer. Video confrence. sesuai dengan namanya merupakan alat untuk berbicara dengan pihak lain secara langsung dengan gambar rekan yang dihubunginya.

Kontrak dengan media chatting dan video conference tersebut pada dasarnya sama dengan pembuatan kontrak konvensional. $\mathrm{Hal}$ yang membedakannya hanyalah pada posisi dan lokasi para pihak yang berlainan.

Kontrak melalui e-mail dapat berupa kontrak e-mail murni di mana penawaran yang dikirim kepada seseorang atau kepada banyak orang yang tergabung dalam sebuah mailing list, penerimaan dan pemberitahuan penerimaan seluruhnya dikirimkan melalui $e$ mail. Kontrak melalui e-mail dapat pula berupa gabungan beberapa formula yang ketika penawaran barangnya diberikan situs web yang mengirimkan penawarannya, dan penerimaannya dikirim melalui e-mail.
Kontrak melalui e-mail ini dikaitkan dengan kontrak konvensional tidak begitu menimbulkan persoalan, karena peraturan yang berkaitan dengan surat dapat diterapkan dalam kontrak lewat e-mail.

Teknologi memungkinkan para pelaku bisnis untuk bergelut dengan webpage (halaman situs), sehingga mampu menjadikan proses kontrak sebagai lembaga intelejen elektronik, yakni sebuah program yang menggunakan stik informasi atau informasi internal untuk menjelaskan responrespon yang ditunjukkan halaman berikutnya dari sebuah kontrak.

Kontrak melalui web biasanya kompleks, karena melibatkan pihak-pihak di luar pihak yang mengadakan kontrak. Pihak-pihak yang terkait diantaranya adalah: pihak-pihak otentifikasi (penyedia sertifikat digital), lembaga keuangan yang memfasilitasi pembayaran melalui web, pemberi label yang mensertifikasi yang menyatakan bahwa halaman web tersebut adalah aman.

Berdasarkan syarat-syarat hukum kontrak konvensional, maka apabila dikaitkan dengan sistem electronic contract atau online contract ${ }^{28}$ akan sangat sulit untuk diterapkan dan mampu memberi jaminan kepastian hukum. Begitu pula dari sudut pandang prinsip-prinsip hukum kontrak ini, tampak bahwa prinsip-prinisip hukum kontrak ini akan mengalami

${ }^{28}$ Dalam tulisan ini penulis berpersepsi bahwa electronic contract dengan online contract mempunyai arti yang sama. Adapun arti dari online contract menurut Elizabeth $S$. Perdue menyatakan An online contract is a contract created wholly or in part through communications over computer networks. Thus contract can be created by e-mail, through Web sites, via electronic data interchange, and other techniques. Lihat Thomas $J$. Smedinghoff (ed). Ibid. 
problematika ${ }^{29}$ apabila diterapkan dalam hukum electronic contract atau online contract.

Sebagai bukti tidak adanya jaminan kepastian hukum dapat dilihat dari adanya inkonsistensi penafsiran hakim. Model interpretasi hakim yang sudah dilakukan di Amerika Serikat. Menurut New Hampshire Supreme Court dalam kasus Howley v. Whipple menyatakan bahwa telegraph merupakan bentuk tertulis. Dalam kasus Dept. of Transportation v. Norris, the Georgia Court of Appeals menyatakan bahwa fax tidak dapat dijadikan persyaratan dalam undang-undang yang oleh departemen transportasi diberitahukan sebagai gugatan atas perbuatan melawan hukum. ${ }^{30}$

Sebagai sebuah kesadaran dari tidak dapat menjangkaunya hukum kontrak konvensional terhadap permasalahan online contract beberapa negara secara individual telah ada yang memformulasikan aturan hukum kontrak yang didasarkan pada perkembangan teknologi komunikasi baru. Sebagai contoh seperti Negara Bagian Utah yang telah menetapkan peraturan secara komprehensif tentang teknologi secara khusus. Negara Bagian lainnya, seperti California yang telah mengusahakan pengakomodiran teknologi khusus oleh penetapan peraturan yang mengakui beberapa perbedaan teknologi agar hukum dapat efektif. Masih ada contoh yang lainnya, seperti Negara Bagian Illinois yang telah menetapkan peraturan yang mencoba membatasi kontrak elektronik secara umum, di lain pihak juga menetapkan secara khusus konsekuensi hukum untuk menggunakan kontrak teknologi elektronik yang lebih dapat dipercaya. ${ }^{31}$

Di samping itu, ada juga bentuk-bentuk Model Law yang dapat dijadikan percontohan bagi negara-negara bagian yang ingin membuat regulasi hukum kontrak elektroniknya. Model Law The Uniform Commercial Code (UCC) yang merevisi istilah media-neutral șeperti rekaman (record) dan autentikasi (authenticate) yang disubstitusi untuk istilah tertulis (writing) dan tanda tangan (signature) yang mungkin diinterpretasikan sebagai persyaratan dokumen kertas atau tanda tangan manual. Dalam Model Law ini misalnya The Uniform Electronic Transaction Act (UETA) ditandai dengan pembatasan

${ }^{29}$ Problematika yang dimaksudkan disini baik dari segi yuridis maupun teknis dalam penyusunan'kontrak elektronik. Dari segi yuridis, apabila kontrak yang dibuat oleh para pihak yang berbeda sistem hukum yang dianutnya, maka akan menimbulkan permasalahan interyurisdiksi. Meskipun hal ini dapat disiasati dengan menerapkan Hukum Perdata Internasional, tetapi ini prosesnya akan sangat kompleks. Di samping itu juga akan sangat sulit dalam hal penentukan kesepakatan apabila masih menggunakan aturan hukum kontrak yang ada di dalam KUHPerdata. Secara teknis, seperti diketahui transaksi yang menggunakan kontrak elektronik sifatnya tidak face to face, jadi akan sangat sulit untuk menentukan apakah seseorang itu cakap hukum atau tidak. Padahal dalam Pasal 1320 KUHPerdata salah satu syarat sahnya kontrak itu para pihak harus dinyatakan cakap secara hukum.

${ }^{30}$ Benjamin Wright \& Jane K. Winn. 2000. The Law of Electronic Commerce. Third Edition; Aspen Law \& Business. New York. HIm.14-4.

${ }^{31}$ lbid. 
e-commerce, sedangkan di sisi lain menetapkan. revisi substansi hukum konvensional secara lebih luas. Model Law lainnya adalah The Uniform Computer Transaction Act (UCITA) yang merupakan Model Law baru yang mengatur transaksi dalam lingkup informasi komputer, seperti software, electronic databases, atau multimedia. UCITA membatasi kontrak elektronik tetapi hanya untuk transaksi dalam lingkupnya. ${ }^{32}$ Selanjutnya Model Law on Electronic Commerce of the United Nations Commission on International Trade Law (UNCITRAL) menawarkan hal yang sama. ${ }^{33}$ Model Law ini yang menyatakan:

"In the context of contract formation, unless othenwise agreed by the parties, an offer and the acceptance of an offer may be expressed by means of data messages. Where a data message is used in the formation of a contract, that contract shall not be denied validity or enforceability on the sole ground that a data message was used for that purpose or stored by electronic, optical or similar means, including electronic mail".

Di kalangan Masyarakat Ekonomi Eropa dalam upaya merespon perkembangan teknologi informasi, mereka telah memberikan garis-garis petunjuk kepada para negara anggotanya guna menjamin terlaksananya dengan tertib dan guna menghilangkan keragu-raguan dalam proses terciptanya penawaran penerimaan dalam masalah kontrak melalui media elektronik. Semula petunjuknya dikenal dengan sistem "3 klik". Pertama, setelah calon pembeli melihat di layar komputernya ada penawaran dari calon penjual (klik pertama), maka si calon pembeli memberikan penerimaan terhadap penawaran tersebut (klik kedua). Sebagai peneguhan dan persetujuan dari calon penjual kepada calon pembeli perihal diterimanya penerimaan dari calon pembeli (klik ketiga). Dengan demikian adanya penawaran dan penerimaan melalui media elektronik dapat dikukuhkan. ${ }^{34}$

Permasalahan yang mendasar dari kegiatan e-commerce tidak hanya terkait pada aspek interyurisdiksi sebagai hasil yang alamiah dari jaringan lintas batas, tetapi juga menyangkut aspek penggunaan istilah-istilah kontrak yang harus dibentuk. Sepertinya masalah ini akan meningkat karena memerlukan pertimbangan dari setiap peraturan antar negara, sehingga hal ini akan membawa konsekuensi pada kebebasan berkontrak dalam yurisdikasi di mana kontrak itu di bentuk dan tunduk pada pilihan hukum kontrak.

Sejalan dengan itu pula, biasanya para pihak ketika melakukan kerja sama bisnis senantiasa menerapkannya dalam bentuk kontrak yang dituangkan dalam kertas sebagai landasan hukumnya. ${ }^{35}$ Jika para pihak

\section{${ }^{32}$ /bid.}

${ }^{33}$ Michael Chissick and Alistair Kelman. 1999. Electronic Commerce Law and Practice. Sweet \& Maxwell. London. HIm. 54.

${ }^{34}$ Setiawan,"Electronic Commerce Tinjauan dari Segi Hukum Kontrak Suatu Catatan Singkat." Varia Peradilan Majalah Hukum, Tahun XV. No. 176 Mei 2000. HIm 115.

${ }^{35}$ Kontrak biasanya tidak mewajibkan harus dibuat dalam bentuk tertulis dan ditanda tangani, tetapi kontrak juga dapat dituangkan dalam bentuk lisan. 
menghendaki bentuk kontrak dengan menggunakan komunikasi elektronik, ${ }^{36}$ maka hal ini telah menyebabkan terjadinya perubahan hukum kontrak konvensional yang memerlukan penjelasan dari keabsahan kontrak itu.

Dalam penyusunan kontrak ada beberapa aspek yang sangat mempengaruhi baik secara eksplisit maupun implisit. Hal ini seperti peraturan mengenai penyusunan kontrak, pilihan hukum (choice of law), pilihan jurisdiksi (choice of jurisdiction), identitas dari para pihak, istilah dan syarat-syarat, penegakan dari kontrak, apakah kontrak mengikat bagi pihak ketiga, dan apakah kontrak dibuat dengan sebenarnya.

Dalam kenyataannya tidak semua transaksi elektronik atau komunikasi dituangkan dalam bentuk kontrak. Ada beberapa klasifikasi pesan elektronik yang didasarkan pada perbedaan permasalahan hukumnya. Pesan elektronik itu antara lain: ${ }^{37}$

1. Penyaluran yang semata-mata hanya informasi (transmission of mere information). Kategori pesan atau informasi ini tidak membawa konsekuensi hukum. Dengan catatan pengirim sendiri berkewajiban untuk dapat menjamin bahwa informasi tersebut benar.
2. Penyaluran dari pemberitahuan yang sifatnya unilateral (transmission of unilateral notices).

Katagori ini menghendaki akibat hukum dan biasanya dibuat dalam bentuk kontrak konvensional.

3. Pesan dalam bentuk kontrak (contract formation messages).

Untuk contoh barang yang dipesan dengan menggunakan pesan elektronik mensyaratkan perlunya bentujk kontrak. Pesan ini adalah bagian yang meliputi negosiasi, perintah dan penerimaan.

Dari bentuk komunikasi yang semakin meningkat ini ternyata telah menimbulkan banyak pertanyaan hukum. Pertama, Dapatkah kontrak itu dibuat dengan menggunakan pesan elektronik? Kapan dan di mana persetujuan itu dibuat? Jika istilah kontrak kemudian menimbulkan sengketa, mungkinkah dapat dibuktikan berdasarkan persetujuan?

Secara khusus formalitàsnya kontrak dibuat secara tertuliș, tetapi secara umum kontrak juga dapat dibentuk secara lisan seperti yang sering terjadi dalam transaksi yang dilakukan di toko-toko kecil. Hal ini tentunya secara teoritikal tidak menimbulkan keberatan apabila dipersamakan untuk menggunakan pesan elektronik dalam

${ }^{36} \mathrm{Hal}$ ini terjadi merupakan pengembangan dari asas kebebasan berkontrak (freedom of contract) yang artinya para pihak dapat menyusun dan menentukan isi kontrak berdasarkan kehendak dari para pihak asalkan kontrak itu sifatnya tidak bertentangan dengan undang-undang, ketertiban umum, dan kesusilaan. Lihat Ridwan Khairandy. Op.Cit. HIm 93. Lihat Juga Sutan Remy Sjahdeini. 1993. Kebebașan Berkontrak dan Perlindungan yang Seimbang Bagi Para Pihak dalam Perjanjian Kredit Bank di Indonesia. Jakarta: Institut Bankir Indonesia.

${ }^{37}$ Chris Reed and Lars Davies. 2000. "Electronic Commerce." Dalam Chris Reed dan Joh'n Angel (eds). Computer Law. Fourth Edition. Blackstone Press Limited. London. HIm.302. 
pembentukan kontrak. Untuk pembentukan kontrak yang menggunakan pesan elektronik para sarjana hukum di negara yang menganut sistem common law berpendapat jika penerimaan itu dibuat dalam bentuk tertulis, maka yang diterapkan adalah sistem postal rule. Artinya bahwa penerimaan didasarkan pada tempat di mana surat itu diposkan. Sistem ini dapat diterapkan dalam sistem penerimaan pesan elektronik. Ada dua alasan yang mendasarinya, yakni; Pertama bahwa itu merupakan' metode kerja pemecahan. ${ }^{38}$ Putusan Lord Brandon dalam Brinkibon Ltd. $v$ Stahag Stahl und Stahiwarenhandelgesellschaft mbH (1982) 1 All ER 293 mengusulkan bahwa postal rule harus diterapkan dalam penerimaan elektronik. Kedua, bahwa penawar yang secara implisit menyetujui bahwa pihak yang menerima mempercayakan transmisi penerimaannya untuk tidak tergantung pada pihak ketiga, kewenangan memposkan.

Lain halnya bagi Indonesia, ternyata sampai kini pemerintah ${ }^{39}$ belum begitu banyak merespon perkembangan teknologi yang berkembang sangat pesat. Jika diperhatikan instrumen hukum yang tersedia, khususnya hukum kontrak, maka problemnya sama dengan hukum kontrak konvensional di negara lain..$^{40}$ Oleh karenanya, perlu dipikirkan pembaharuan hukum ${ }^{41}$ yang mengakui keabsahan dari sebuah electronic contract.

\section{Bentuk Pengaturan}

Ada kebutuhan untuk mengatur hubungan hukum yang timbul dalam transaksi yang dilakukan melalui internet. Sekarang timbul permasalahan apakah pembaharuan dan penciptaan hukum baru itu dilakukan secara integral dalam bentuk cyberlaw atau hukum telematika ataukah secara parsial sesuai bidang-bidang yang menjadi bagian cyberlaw atau telematika itu.

Di Amerika Serikat, pengaturan cyberlaw. tidak dituangkan dalam satu undang-undang tertentu. Amerika Serikat antara lain memiliki The Digital Signature Act of 1999 yang ditujukan untuk mengatur standar tanda tangan elektronik dan kontrak. Ketentuan ini

${ }^{38}$ Meskipun hal ini menjadi sebuah pertanyaan yang tak terelakan, jika peraturan (rule) menyatakan bahwa surat sudah diterima, akankah itu relevan bahwa surat itu tiba tetapi tidak pernah di baca atau tidak dibaca sebelum penarikan dari penawaran.

${ }^{39} \mathrm{Pemerintah} \mathrm{di} \mathrm{sini} \mathrm{diartikan} \mathrm{sebagai} \mathrm{lembaga} \mathrm{yang} \mathrm{mempunyai} \mathrm{kewenangan/otoritas} \mathrm{untuk} \mathrm{membuat}$ peraturan perundang-undangan terutama adalah lembaga legislatif dan eksekutif, dalam hal ini DPR beserta Presiden.

${ }^{40}$ Dalam konteks ini akan sangat sulit menentukan kapan terjadinya kesepakatan antar pihak..... Tapi di sisi lain pakar hukum teknologi dari UI berpendapat sebenarnya hukum konvensional telah mengatur dan mengantisipasi perkembangan teknologi, namun, justru yang jadi masalah adalah tidak efektifnya struktur hukum yang ada. Lihat di http://www.hukumonline.com. Tanggal 8 Agustus 2001.

4'Pembaharuan hukum kontrak yang dimaksudkan bukan dalam arti tidak mengindahkan prinsip-prinsip umum atau asas-asas dari hukum kontrak itu sendiri, serta dalam proses pembaharuan itu seharusnya tetap memperhatikan pengaturan hukum yang ada baik di level nasional maupun intemasional. Adapun untuk penerapan hukum dalam konteks kasus-kasus yang terjadi sekarang dapat diterapkan dengan cara menerapkan hukum konvensional sembari membuat aturan-aturan hukum baru di bidang cyberspace, termasuk kontrak. 
dimaksudkan untuk memberikan perlindungan konsumen dari perusahaan yang mencoba untuk berbuat confuse dengan electronic disclosure atau memaksa mereka untuk melepaskan hak mereka terhadap paper record. ${ }^{42}$ Berkaitan dengan pengaturan domain names, Amerika Serikat telah menambahkan Pasal 43 (d) Trademark Act of 1946, Lanham Act yang diamandemen. Pasal 43 (d) mengatur mengenai cyberpiracy prevention.

Singapura telah memiliki The Electronic Transaction Act. Dalam penyusunan undangundang ini, Singapura mengadopsi hukum yang sebangun dari tiga negara bagian di Amerika Serikat (Illinois, Florida, dan Utah), hukum Jerman, dan UNCITRAL Model Law on Electronic Commerce. ${ }^{43}$ Australia juga telah mengadopsi model law yang dibuat UNCITRAL tersebut ke dalam The Electronic Transaction Bill 1999.

Walaupun pembaharuan dan penciptaan hukum baru itu tidak dituangkan dalam satu undang-undang tertentu, tetapi substansi yang diaturnya harus terintegrasi dalam satu sistem. Pembaharuan hukum kontrak, tidak dapat dilakukan secara terpisah dengan pembaharuan hukum acara, khususnya berkaitan dengan hukum pembuktian. Pembaharuạn hukum kontrak juga tidak dilepaskan untuk pembangunan kaidah-kaidah hukum perdata internasional yang baru, mengingat transaksi bisnis melalui internet banyak mengandung hukum perdata internasionalnya.

Pembentukan hukum di dalam dunia maya ini dapat juga. dibentuk melalui kristalisasi kebiasaan di dalam praktek transaksi komersial yang pada akhirnya membentuk suatu hukum kebiasaan (customary law). Kemungkinan terbentuknya hukum kebiasaan dalam dunia maya ini diintrodusir oleh Elizabeth Longworth ${ }^{44}$ dengan menganalogikan terciptanya lex mercatoria ${ }^{45}$ dalam perdagangan internasional.

Pembentukan hukum yang berkaitan transaksi komersial ini dapat pula dilakukan pembentukan yurisprudensi (case law). Justeru yurisprudensi ini yang seharusnya dituntut berperan banyak dalam pembentukan kaidahkaidah hukum ekonomi.

Undang-undang apapun yang tidak sempurna. Tidak mungkin mengatur segala aspek kehidupan manusia secara tuntas. Hukum bukan sesuatu yang statis. Hukum adalah 'bagian dari masyarakat. Oleh karena itu, hukum tumbuh dan berkembang bersama masyarakat itu sendiri. ${ }^{46}$ Pendapat yang ekstrim menyatakan bahwa begitu suatu aturan dikodifikasikan, pada saat yang sama ia akan

${ }^{42}$ Assafa Endeshaw. Op.Cit, HIm 451.

${ }^{43} \mathrm{Ibid}$. HIm 268.

${ }^{44}$ Elizabeth Longworth, "The Possibilities for a Legal Framework for Cyberspace - Including a New Zealand Perspective", Bruno de Padirac (General Editor). 2000. The Intemational Dimension of Cyberspace Law. UNESCO - Asgate Daemouth, Alderhot. HIm 30

${ }^{45}$ Lex mercatoria pada dasarnya hukum kebiasaan yang isinya berupa prinsip-prinsip dan kebiasaankebiasaan yang telah diterima secara umum dalam praktek perdagangan internasional tanpa merujuk kepada suatu hukum sistem hukum nasional tertentu. Dengan demikian lex mercatoria adalah norma hukum yang bersifat otonom, suatu norma yang berlaku di kalangan masyarakat bisnis. Lihat Ridwan Khairandy, et.al, 1999. Pengantar Hukum Perdata Internasional/ndonesia, Pusat Studi Hukum FH UII-Gama Media. Yogyakarta. HIm 112. 
ketinggalan jaman. ${ }^{47}$ Adakalanya undangundang tidak lengkap dan adakalanya tidak jelas, meskipun tidak lengkap atau tidak jelas, undang-undang harus tetap dilaksanakan. ${ }^{48}$ Kekosongan dan ketidakjelasan hükum tersebut harus diisi oleh pengadilan. Dengan demikian yurisprudensi memiliki arti yang sangat penting dalam penegakan hukum. Untuk menunjang kewenangan yang dimiliki hakim sebagai judge as law makers dikaitkan dengan perkembangan teknologi informasi dewasa ini, tentunya peningkatan sumber daya manusia pengadilan menjadi suatu hal yang tidak terelakkan.

\section{Simpulan}

Bentuk kontrak dalam aktivitas electronic commerce pada hakekatnya disebut dengan online contract atau electronic contract. Karakteristik dari online contract sangat berbeda dengan kontrak konvensional. Oleh karena itu, pembaharuan hukum kontrak dalam aktivitas electronic commerce menjadi sesuatu yang urgen. Pembaharuan hukum kontrak dapat mengacu kepada Model Law of Electronic Commerce atau kepada peraturan perundang-undangan negara yang mengatur hal itu. Pembentukan norma hukum untuk transaksi tersebut di atas dapat melalui jalur legislasi, hukum kebiasaan (lex mercatoria) maupun melalui yurisprudensi. $\square$

\section{Daftar Pustaka}

Adnan, Muhammad Aulia. "Aspek Hukum Protokol Pembayaran Visa/Mastercard Secure Electronic Transaction (SET)." Skripsi. Fakultas Hukum Universitas Indonesia. Depok Jawa Barat. 2001.

Badrulzaman, Mariam Darus. 1994. Aneka Hukum Bisnis. Bandung: Alumni.

Bajaj, Kamlesh K \& Debjani Bag. 2000. ECommerce The Cutting Edge of Business. Diterjemahkan oleh Imam Mawardi, Surabaya: PT Akana Press Offset.

Cheseeman, Henry R.. 1995. Business Law: The Legal, Ethical and International Environment. New Jersey: Prentice Hall.

Chissick, Michael and Alistair Kelman. 1999.

Electronic Commerce Law and Practice. London: Sweet \& Maxwell.

Ding, Julian. 1999. E-Commerce: Law and Practice. Malayasia: Sweet \& Maxwell.

Endeshaw, Assafa. 2001.Internet and ECommerce Law with Focus on Asia Pasific. Singapore: Prentice Hall.

Gamer, Bryan A. 1999. Black's Law Dictionary. Seven Edition. St. Paul Minn: West Group.

Haanappel, P.P.C. dan Ejan Mackaay. 1990. Nieuw Nederlands Burgerlijk Wetboek: Het Vermogenrechts. Deventer: Kluwer.

\footnotetext{
${ }^{46}$ Setiawan, "Publikasi Putusan Hakim". Varia Peradilan, Tahun VIII No. 95m Agustus 1993. HIm ${ }^{47}$ Ibid.

${ }^{48}$ Sudikno Mertokusumo dan A. Pitlo. 1993. Bab-Bab tentang Penemuan Hukum. Citra Aditya. Bandung.
} HIm. 3. 
http://www.law.gov.au/aghome/advisory/ eceg/single.htm

http://www.hukumonline.com. Tanggal 8 Agustus 2001

Khairandy, Ridwan. "Kewenangan Hakim untuk Melakukan Intervensi terhadap Kewajiban Kontraktual Berdasarkan Asas Iktikad Baik." Jurnal Hukum No. 15. Vol 7 :Desember 2000.

Khairandy, Ridwan, et.al.1999. Pengantar Hukum Perdata Internasional Indonesia. Yogyakarta: Pusat Studi Hukum Fakultas Hukum UII - Gama Media.

Klomp, R.J.Q. (Red). 1997. Burgerlijk Wetboek 1997/1998 Boeken 1 t/m 8. Nijmegen: Ars Aqequi Libr.

Mertokusumo, Sudikno dan A.Pitlo. 1993. BabBab tentang Penemuan Hukum. Bandung: Citra Aditya Bakti.

Padirac, Bruno de (Ed). 2000. The International Dimension of Cyberspace Law. Alderhot: UNESCO-Asgate Daemouth.

Reed, Chris dan John Angel (eds). 2000. Computer Law. Fourth Edition. Aldine Place London: Balckstone Press Limited.

Satrio, J. 1995. Hukum Perikatan, Perikatan yang Lahir dari Perjanjian Buku I. Bandung: Citra Aditya Bakti.

,1995. Hukum Perikatan, Perikatan yang Lahir dari Perjanjian Buku II. Bandung: Citra Aditya Bakti.
Setiawan."Electronic Commerce Tinjauan dari Segi Hukum Kontrak Suatu Catatan Singkat." Varia Peradilan. Tahun.XV. №. 176 Mei 2000.

,Publikasi Putusan Hakim". Varia Peradilan. Tahun VIII No. 95 Agustus 1993.

Sjahdeini, Sutan Remy. 1993. Kebebasan Berkontrak dan Perlindungan yang Seimbang Bagi Para Pihak dalam Perjanjian Kredit Bank di Indonesia. Jakarta: Institut Bankir Indonesia.

Smedinghoff, Thomas J. (ed). 1996. Online Law: The SPA's Legal Guide To Doing Business on The Internet. The Sofware Publishers Association: Wesley Publishing Company. Inc.

Turban, Efraim, et,al. 1999. Electronic Commerce Perspective Managerial. Upper Saddle River New Jersey: Prentice-Hall. Inc.

Wibowo, Arrianto Mukti, et,al. "Kerangka Hukum Digital Signature Dalam Electronic Commerce." Makalah disampaikan pada Masyarakat Telekomunikasi Indonesia. Diselenggarakan oleh UI. Depok Jawa Barat. Juni 1999.

Wright, Benjamin \& Jane K. Winn. 2000. The Law of Electronic Commerce. Third Edition. New York: Aspen Law \& Business. 